\title{
Translation and validation of the Uterine Fibroid Symptom and Quality of Life (UFS-QOL) questionnaire for the Brazilian Portuguese language
}

\author{
Tradução e validação do questionário Uterine Fibroid Symptom and Quality of Life \\ (UFS-QOL) para a língua portuguesa brasileira
}

\author{
Luiz Gustavo Oliveira Brito', Daniela Alves Malzone-Lott', Mayra Fernanda Sandoval Fagundes", Pedro Sérgio Magnani"', \\ Mariana Alves Fernandes Arouca'v, Omero Benedicto Poli-Netov ${ }^{v}$, Antônio Alberto Nogueirav
}

Department of Gynecology and Obstetrics, Faculdade de Medicina de Ribeirão Preto (FMRP), Universidade de São Paulo (USP), and

School of Medicine, Universidade de Ribeirão Preto (UNAERP), Ribeirão Preto (SP), Brazil

\begin{abstract}
'MD, PhD. Attending Physician, Department of Gynecology and Obstetrics, Faculdade de Medicina de Ribeirão Preto (FMRP), Universidade de São Paulo (USP), and School of Medicine, Universidade de Ribeirão Preto (UNAERP), Ribeirão Preto (SP), Brazil.

"MD. Physician, Department of Gynecology and Obstetrics, Faculdade de Medicina de Ribeirão Preto (FMRP), Universidade de São Paulo (USP), Ribeirão Preto (SP), Brazil.

"'MD. Attending Physician, Department of Gynecology and Obstetrics, Faculdade de Medicina de Ribeirão Preto (FMRP), Universidade de São Paulo (USP), Ribeirão Preto (SP), Brazil. "MD, MSc. Attending Physician, Department of Gynecology and Obstetrics, Faculdade de Medicina de Ribeirão Preto (FMRP), Universidade de São Paulo (USP), Ribeirão Preto (SP), Brazil. $\mathrm{MD}$, PhD. Associate Professor, Department of Gynecology and Obstetrics, Faculdade de Medicina de Ribeirão Preto (FMRP), Universidade de São Paulo (USP), Ribeirão Preto (SP), Brazil.
\end{abstract}

\section{KEY WORDS:}

Leiomyoma.

Validation studies [publication type].

Translations.

Quality of life.

Cross-sectional studies.

PALAVRAS-CHAVE:

Leiomioma.

Estudos de validação.

Traduções.

Qualidade de vida.

Estudos transversais.

\begin{abstract}
CONTEXT AND OBJECTIVE: Uterine fibroids (UF), also known as leiomyomas, are the most prevalent gynecological tumors. The Uterine Fibroid Symptoms and Quality of Life (UFS-QOL) is the only specific questionnaire that assesses symptom intensity and quality-of-life issues for women with symptomatic UF; however, it only exists in the English language. Thus, we aimed to translate and culturally validate the UFS-QOL questionnaire for the Brazilian Portuguese language.

DESIGN AND SETTING: Cross-sectional study, Department of Gynecology and Obstetrics, FMRP-USP.

METHODS: 113 patients with UF (case group) and 55 patients without UF (control group) were interviewed using the UFS-QOL questionnaire after translation and cultural adaptation. The Short Form-36 questionnaire was used as a control. Demographic and psychometric variables were analyzed.

RESULTS: Women with UF presented higher mean age, body mass index, weight, parity and comorbidities than the control group $(P<0.05)$. The most prevalent complaints were abnormal uterine bleeding (93.8\%), pelvic pain (36.3\%) and extrinsic compression (10.6\%) and these presented adequate construct validity regarding UFS-QOL severity $(P<0.05)$. The UFS-QOL questionnaire presented good internal consistency regarding symptom severity and quality-of-life-related domains (intraclass correlation coefficient, ICC $=0.82 / 0.88$ ). Structural validity presented correlation coefficients ranging from 0.59 to 0.91 . Test-retest comparison did not show differences among the UFS-QOL subscales. After treatment, women with UF presented improvements on all subscales.

CONCLUSION: The UFS-QOL questionnaire presented adequate translation to the Brazilian Portuguese language, with good internal consistency, discriminant validity, construct validity, structural validity and responsiveness, along with adequate test-retest results.
\end{abstract}

\section{RESUMO}

CONTEXTO E OBJETIVO: O leiomioma uterino (LU) é o tumor ginecológico mais comum. Existe apenas um questionário específico que avalia a intensidade de sintomas e qualidade de vida de mulheres com LU sintomático, o Uterine Fibroid Symptom and Quality of Life (UFS-QOL), porém somente na língua inglesa. Dessa forma, objetivamos traduzir e validar culturalmente o questionário UFS-QOL para a língua portuguesa brasileira.

TIPO DE ESTUDO E LOCAL: Estudo transversal, Departamento de Ginecologia e Obstetrícia da FMRP-USP. MÉTODOS: 113 pacientes portadoras de LU (grupo caso) e 55 pacientes-controle foram entrevistadas com o questionário UFS-QOL após tradução e adaptação cultural. O questionário Short Form-36 foi utilizado para controle. Variáveis demográficas e psicométricas foram analisadas.

RESULTADOS: As mulheres com LU apresentaram maior média de idade, índice de massa corporal, peso, paridade e comorbidades do que o grupo controle $(P<0,05)$. As queixas mais prevalentes foram sangramento uterino anormal (93,8\%), dor pélvica (36,3\%) e compressão extrínseca $(10,6 \%)$ e estas apresentaram adequada validade de constructo com a gravidade indicada pelo UFS-QOL $(P<0,05)$. O questionário UFS-QOL apresentou boa consistência interna com a gravidade dos sintomas e com os domínios relacionados a qualidade de vida (coeficiente de correlação intraclasse, $\mathrm{CCl}=0,82 / 0,88$ ). A validade estrutural mostrou coeficientes de correlação variando de 0,59 até 0,91 . A comparação teste-reteste não mostrou diferença entre as subscalas do UFS-QOL. Depois do tratamento, as mulheres com LU apresentaram melhora em todas as subscalas. CONCLUSÃO: O questionário UFS-QOL apresentou adequada tradução para a língua portuguesa brasileira, com boa consistência interna, validade de constructo/discriminatória, estrutural e responsividade, assim como adequados resultados teste-reteste. 


\section{INTRODUCTION}

Uterine fibroids (UF), also known as leiomyomas, are the most common gynecological tumors and they originate from the smooth muscle cells of the uterine wall. Although 60 to $80 \%$ of women present these tumors, ${ }^{1}$ only 20 to $30 \%$ present symptoms, such as abnormal uterine bleeding and pelvic pain. ${ }^{2}$ In Brazil, there are no accurate epidemiological data for this disease; however, the number of hysterectomies performed in this country has stabilized, ${ }^{3}$ even though clinical management of UF is still a challenge. ${ }^{4}$

An observational study showed that UF had a negative impact on the patients' quality of life. ${ }^{5}$ They presented social and professional limitations, with fear, disbelief and despondency regarding their symptoms, and these factors strengthened their will to undergo hysterectomy. ${ }^{6}$ Thus, the impact of UF symptoms on women's health-related quality of life (HRQL) is a major indicator for treatment.

Questionnaires may be useful for measuring the impact of symptoms and the results from clinical and/or surgical interventions. Fourteen years ago, the only questionnaire directed towards UF, the Uterine Fibroid Symptom and Quality of Life (UFS-QOL) questionnaire, was published. ${ }^{7}$ The responsiveness of this questionnaire was subsequently assessed ${ }^{8}$ and it was validated in a non-randomized prospective study. ${ }^{9}$ Thus, many studies that have investigated UF have been using this questionnaire.

To our knowledge, from searching in the literature, there is no cultural translation/validation of the UFS-QOL questionnaire in the Brazilian Portuguese language. A simple translation is not valid for use, given that it is known that adapting questionnaires to the local language is a difficult task. ${ }^{10}$ Moreover, regional expressions should be incorporated and therefore there is a need to conduct a study to confirm the cultural validity of the questionnaire.

\section{OBJECTIVE}

The authors aimed to translate and culturally validate the UFS-QOL questionnaire for the Brazilian Portuguese language.

\section{METHODS}

\section{Type of study and patients}

A cross-sectional study was conducted at the Gynecological Surgery Clinic of Hospital das Clínicas, Faculdade de Medicina de Ribeirão, Universidade de São Paulo (HCFMRP-USP), between April and September 2015. Women were recruited through the consultations that are provided in this setting and were treated by means of clinical or surgical management. The control group was constituted by women from other outpatient gynecological clinics at HCFMRP-USP who did not present abnormal uterine bleeding or pelvic pain as their main complaints.
The inclusion criteria were that the subjects should be women of fertile age presenting UF with complaints of abnormal uterine bleeding or pelvic pain or a sensation of external compression. We excluded pregnant women, those who were using anticoagulants or presented abnormal uterine bleeding of other secondary causes (endometrial or ovulatory), and those with cognitive impairments or who were illiterate.

All participants signed an informed consent statement and this study was approved by our Institutional Review Board (procedural number 531.584). This study was drawn up in accordance with the ethical guidelines of the 1975 Declaration of Helsinki.

\section{UFS-QOL questionnaire: translation and validation}

The UFS-QOL questionnaire specifically assesses severity of symptoms (8 questions) and HRQL (29 questions) among women with UF. The HRQL scale comprises the following subscales: concern, activities, energy/mood, control, self-consciousness and sexual function. ${ }^{7}$ All answers have five options on a Likert scale. The higher the score on the severity subscale of the questionnaire is, the greater the severity of symptoms is; while the lower the scores on the HRQL subscales are, the poorer the quality of life is.

Written authorization was firstly obtained from the Society for Interventional Radiology and from Prof. James Spies to translate and validate the UFS-QOL questionnaire. Following this, the initial translation was performed by two notarized bilingual professors. This translation was evaluated by a committee composed of three gynecologists (LGOB, DAML and MAFA) and was pilottested on ten women who were attended in the outpatient setting. These patients were asked about any difficulties in comprehending the questionnaire. Some words were adapted by the interviewer to ease their understanding. The changes thus made were reviewed by the same medical committee and the final version was released for application. A back translation was performed by a native speaker of English who had knowledge of the Portuguese language. The final questionnaire was submitted to and received consent for publication from the Society for Interventional Radiology. ${ }^{11}$

There was no standardization regarding the mode of application of the questionnaire (oral interview or self-application). However, most of the questionnaires were self-administered by the patients, with the option of asking the interviewer for help if any queries arose while answering the questionnaire.

In addition, the Short Form-36 (SF-36) questionnaire was used as a control, to make comparisons with the UFS-QOL questionnaire and thus calculate its construct validity. The SF-36 questionnaire measures HRQL using eight domains: vitality, physical functioning, bodily pain, general health perceptions, physical role functioning, emotional role functioning, social role functioning and mental health. ${ }^{12}$ The individual items from each subscale are 
combined to form an overall score, which is then transformed into a score from 0 to 100 . Higher scores indicate better HRQL. ${ }^{13}$

\section{Variables}

The following demographic data were obtained: age, weight, height, body mass index (BMI), gravidity, parity and comorbidities. The following clinical symptoms were investigated: presence of abnormal uterine bleeding, pelvic pain and a sensation of external compression.

With regard to psychometric properties for measuring questionnaires, the variables analyzed were: internal consistency, construct validity, test-retest similarity and responsiveness. Internal consistency assesses the correlation between the items and is determined from the subscale and total scores. Higher values indicate higher correlation among several items on the scales, i.e. one or several items may be measuring the same concept. Values over 0.70 were considered adequate or acceptable. ${ }^{14}$ Construct validity was calculated by comparing the symptoms with the UFS-QOL score response and was considered adequate when different responses were perceived between the groups with and without symptoms. Structural validity was explored by means of principal-component analysis, with standardized coefficients comparing all questions from each quality-of-life subscale with the severity subscale, in order to identify the highest correlation coefficient. It is important to note that this psychometric analysis was previously done by Spies et al., ${ }^{7}$ to individualize the subscales. A retest $(\mathrm{n}=20)$ was performed 1-2 weeks after first application of the questionnaire. Responsiveness ( $\mathrm{n}=44$ ) was assessed after three months of clinical and/or surgical treatment, to ascertain whether the UFS-QOL scores had changed after the first application of the questionnaire.

\section{Statistical analysis}

The data were tabulated in Microsoft Excel (Microsoft Co., Redmond, WA, USA) and statistical analyses were performed by means of Intercooled Stata 13.0 (College Station, TX, USA). A significance level of 5\% was stipulated in all two-sided tests. Normality analysis was performed using the Shapiro-Wilk test, and the continuous variables (age, body mass index and weight) were found to have parametric distribution. The chi-square test was used for binomial variables and Student's t test for continuous variables.

No power calculation was performed, because of the extensive variability of formulae that have been suggested for generating the minimum number of subjects for a given study that involves translating and validating a standardized questionnaire. ${ }^{10}$

The internal consistency was calculated by means of Cronbach's alpha (over 0.9, excellent; 0.7-0.9, acceptable to good; 0.6-0.7, questionable; $0.5-0.6$, poor; and below 0.5 , unacceptable) and by means of item correlation. The structural validity was calculated by means of structural equation modeling between severity and other quality-oflife subscales. Test-retest similarity and responsiveness were calculated using a paired t test, with extraction of the mean and standard deviation and the mean difference between variables.

Missing data were not treated using imputation methods. All patients answered at least $50 \%$ of the questions on both questionnaires.

\section{RESULTS}

The study group was formed by 113 women and the control group by 55 women, thus totaling 168 patients recruited over the study period. We had 5 refusals to participate, and 12 women were excluded from the study (due to cognitive incapacity to understand the questionnaire) during the enrollment period.

The demographic data are described in Table 1. The women with UF presented higher mean age $(42.6 \pm 6.5$ years; $\mathrm{P}<0.005)$, weight $(78.9 \pm 16.7 \mathrm{~kg}), \mathrm{BMI}\left(30.3 \pm 6 \mathrm{~kg} / \mathrm{m}^{2} ; \mathrm{P}=0.01\right)$ and parity $(\mathrm{P}<0.005)$. The presence of comorbidities was higher among women with UF than in the control group, without any statistically significant difference (53.1\% versus $38.2 \%$; $\mathrm{P}=0.069$ ). The most common diseases in the study group were arterial hypertension and anxiety/depressive disorders. Among the clinical symptoms, abnormal uterine bleeding was the most prevalent $(93.8 \%)$, followed by pelvic pain (36.3\%) and external compression (10.6\%).

Table 2 shows the analysis of the UFS-QOL and SF-36 scores in both groups. All UFS-QOL subscales showed statistically significant differences between women with UF and controls $(\mathrm{P}<0.05)$. The women with UF presented higher severity scores and lower scores on the subscales that measured quality of life, compared with the controls. The self-consciousness and sexual function subscales presented greater reductions in mean difference scores between

Table 1. Demographic and clinical baseline characteristics

\begin{tabular}{|c|c|c|c|}
\hline Variables & $\begin{array}{l}\text { Control group } \\
\quad(n=55)\end{array}$ & $\begin{array}{l}\text { Study group } \\
(n=113)\end{array}$ & P-value \\
\hline Age (mean \pm standard deviation) & $37.9(8.2)$ & $42.6(6.5)$ & $<0.005$ \\
\hline Gravidity (median/range) & $1(0-6)$ & $2(0-6)$ & $<0.005$ \\
\hline Parity (median/range) & $1(0-5)$ & $2(0-6)$ & $<0.005$ \\
\hline \multicolumn{4}{|l|}{ Educational level ( $n, \%)$} \\
\hline $0-6$ years & $15(27.3)$ & $44(38.9)$ & \multirow{4}{*}{$<0.005$} \\
\hline $7-12$ years & $21(38.2)$ & $63(55.9)$ & \\
\hline$>12$ years & $18(32.7)$ & $3(2.6)$ & \\
\hline Not informed & $1(1.8)$ & $3(2.6)$ & \\
\hline $\begin{array}{l}\text { Body mass index } \\
\text { (mean } \pm \text { standard deviation) }\end{array}$ & $\begin{array}{c}27.7(5.8) \\
(\mathrm{n}=54)\end{array}$ & $\begin{array}{l}30.3(6.0) \\
(n=110)\end{array}$ & 0.010 \\
\hline Comorbidities (n, \%) & $21(38.18)$ & $60(53.1)$ & 0.069 \\
\hline \multicolumn{4}{|l|}{ Symptoms } \\
\hline Abnormal uterine bleeding & $1(1.8)$ & $106(93.8)$ & $<0.005$ \\
\hline Pelvic pain & $3(5.5)$ & $41(36.3)$ & $<0.005$ \\
\hline External compression & $1(1.8)$ & $12(10.6)$ & $<0.005$ \\
\hline
\end{tabular}


the women with UF and the others. Regarding the SF-36 domains, women with UF presented lower quality of life $(\mathrm{P}<0.05)$ except for the vitality domain $(\mathrm{P}=0.07)$. Thus, discriminant validity could be demonstrated.

The internal consistency calculation on the UFS-QOL questionnaire is shown in Table 3. Values over 0.75 were found for all its subscales and for the HRQL score in the control and study groups, thus showing that the concordance was adequate. Item correlation presented moderate concordance regarding symptom severity. Similarly, in the study group, moderate concordance was seen regarding symptom severity, self-consciousness and sexual function. The construct validity showed statistical significance between the presence of symptoms and higher mean UFS-QOL severity score (Table 4). With regard to responsiveness, all UFS-QOL subscales presented improvement in quality of life and reduction in the severity of symptoms after treatment (Table 5). The analysis on standardized coefficients for quality-of-life subscales, with severity as covariance, showed values ranging from 0.59 to 0.91 , as seen in Table 6. The covariance analysis with severity showed highest correlations with the following subscales: concern (0.91), control (0.80) and self-consciousness (0.81). Finally, no differences were noted in the test-retest comparison of the UFS-QOL version for the Brazilian Portuguese language (Table 7). The final version is presented with this paper (Annex).
Table 2. Discriminant validity of the Uterine Fibroid Symptom and Quality of Life (UFS-QOL) and Short-Form-36 (SF-36) questionnaires among women with uterine fibroids and control patients

\begin{tabular}{lccc} 
& \multicolumn{2}{c}{ Mean (SD) } & \\
\cline { 2 - 3 } Questionnaires & Control group & Study group & P-value \\
\cline { 2 - 3 } & $(\mathbf{n = 5 5 )}$ & $(\mathbf{n}=113)$ & \\
UFS-QOL & & & \\
$\quad$ Symptom severity & $15.7(17.6)$ & $59.4(19.1)$ & $<0.001$ \\
Concern & $95.2(10.9)$ & $33.6(28.7)$ & $<0.001$ \\
Activities & $96.5(10.6)$ & $53.8(26.0)$ & $<0.001$ \\
Energy/Mood & $92.9(18.6)$ & $47.3(28.5)$ & $<0.001$ \\
Control & $94.5(16.2)$ & $51.3(27.3)$ & $<0.001$ \\
Self-consciousness & $94.7(16.2)$ & $49.3(25.7)$ & $<0.001$ \\
Sexual function & $90.7(23.8)$ & $43.9(36.6)$ & $<0.001$ \\
Total Score & $361.7(73.7)$ & $115.7(116.9)$ & $<0.001$ \\
SF-36 & & & \\
Physical functioning & $74.9(32.3)$ & $59.2(29.6)$ & 0.0021 \\
Physical role functioning & $73.2(39.0)$ & $38.3(44.9)$ & $<0.001$ \\
Bodily pain & $62.5(26.2)$ & $52.0(28.4)$ & 0.023 \\
General health perceptions & $58.6(17.9)$ & $50.5(20.2)$ & 0.013 \\
Vitality & $56.9(21.7)$ & $49.6(25.8)$ & 0.072 \\
Social role functioning & $74.8(30.7)$ & $59.9(32.0)$ & 0.003 \\
Emotional role functioning & $72.7(40.1)$ & $44.8(44.5)$ & $<0.001$ \\
Mental health & $60.7(21.5)$ & $50.8(26.5)$ & 0.017
\end{tabular}

Table 3. Internal consistency (ICC) and item correlation among women with uterine fibroids and control group

\begin{tabular}{lcccc} 
UFS-QOL & \multicolumn{2}{c}{$\begin{array}{c}\text { Control group }(\mathbf{n}=\mathbf{5 5}) \\
\text { Cronbach's } \\
\text { alpha }\end{array}$} & $\begin{array}{c}\text { Study group }(\mathbf{n}=\mathbf{1 1 3}) \\
\text { Item } \\
\text { correlation }\end{array}$ & $\begin{array}{c}\text { Cronbach's } \\
\text { alpha }\end{array}$ \\
Symptom severity & 0.59 & 0.84 & 0.65 & 0.82 \\
Concern & 0.84 & 0.84 & 0.80 & 0.80 \\
Activities & 0.89 & 0.83 & 0.81 & 0.81 \\
Energy/mood & 0.96 & 0.81 & 0.86 & 0.80 \\
Control & 0.92 & 0.82 & 0.86 & 0.80 \\
Self-consciousness & 0.90 & 0.82 & 0.66 & 0.82 \\
Sexual function & 0.90 & 0.80 & 0.72 & 0.81 \\
HRQL score & 1.00 & 0.91 & 1.00 & 0.88
\end{tabular}

UFS-QOL = Uterine Fibroid Symptom and Quality of Life; HRQL = health-related quality of life.
Table 4. Construct validity between uterine fibroid symptoms and the Uterine Fibroid Symptom and Quality of Life (UFSQOL) questionnaire

\begin{tabular}{lcccc} 
& $\begin{array}{c}\text { Study group } \\
\text { Mean } \pm \text { standard deviation }\end{array}$ & $\begin{array}{c}\text { Control } \\
\text { group }\end{array}$ & $\begin{array}{c}\text { Mean } \\
\text { difference }\end{array}$ & P-value \\
\cline { 2 - 3 } $\begin{array}{l}\text { Abnormal } \\
\text { uterine }\end{array}$ & $59.57 \pm$ & $19.67 \pm$ & -39.9 & $<0.001$ \\
bleeding & 19.92 & 20.10 & & \\
Pelvic pain & $60.51 \pm$ & $39.61 \pm$ & -20.89 & $<0.001$ \\
External & 20.15 & 28.02 & & \\
compression & $56.00 \pm$ & $44.17 \pm$ & -11.83 & 0.014 \\
\hline
\end{tabular}

Table 5. Responsiveness of women with uterine fibroids after treatment $(n=44)$

\begin{tabular}{|c|c|c|c|c|}
\hline \multirow{2}{*}{ UFS-QOL } & $\begin{array}{c}\text { Before } \\
\text { treatment }\end{array}$ & $\begin{array}{c}\text { After } \\
\text { treatment }\end{array}$ & \multirow{2}{*}{$\begin{array}{c}\text { Mean } \\
\text { difference }\end{array}$} & \multirow{2}{*}{ P-value } \\
\hline & \multicolumn{2}{|c|}{$\begin{array}{c}\text { Mean/standard } \\
\text { deviation }\end{array}$} & & \\
\hline $\begin{array}{l}\text { Symptom } \\
\text { severity }\end{array}$ & $\begin{array}{c}54.97 \\
(14.57)\end{array}$ & $\begin{array}{c}15.05 \\
(17.91)\end{array}$ & -39.91 & $<0.005$ \\
\hline Concern & $\begin{array}{c}32.84 \\
(24.97)\end{array}$ & $\begin{array}{c}86.59 \\
(24.97)\end{array}$ & +53.75 & $<0.005$ \\
\hline Activities & $\begin{array}{c}57.95 \\
(24.96)\end{array}$ & $\begin{array}{c}91.72 \\
(13.81)\end{array}$ & +33.76 & $<0.005$ \\
\hline Energy/mood & $\begin{array}{c}50.08 \\
(28.37)\end{array}$ & $\begin{array}{c}83.76 \\
(22.69)\end{array}$ & +33.69 & $<0.005$ \\
\hline Control & $\begin{array}{c}54.32 \\
(26.86)\end{array}$ & $\begin{array}{c}87.61 \\
(20.50)\end{array}$ & +33.29 & $<0.005$ \\
\hline Self-consciousness & $\begin{array}{c}50.95 \\
(22.68)\end{array}$ & $\begin{array}{c}75.19 \\
(27.70)\end{array}$ & +24.24 & $<0.005$ \\
\hline Sexual function & $\begin{array}{c}43.18 \\
(36.21)\end{array}$ & $\begin{array}{c}65.91 \\
(39.19)\end{array}$ & +22.72 & $<0.005$ \\
\hline HRQL score & $\begin{array}{c}124.42 \\
(108.26)\end{array}$ & $\begin{array}{c}298.09 \\
(110.96)\end{array}$ & +173.68 & $<0.005$ \\
\hline
\end{tabular}

UFS-QOL = Uterine Fibroid Symptom and Quality of Life; HRQL = healthrelated quality of life. 


\section{DISCUSSION}

This study showed that in the UFS-QOL questionnaire, the symptoms of women with UF strongly correlated with lower HRQL subscales and higher severity scores, and thus that the women's symptoms had an impact on their quality of life. No differences with regard to the ICC were seen on the UFS-QOL subscales among the women with UF, although item correlation was moderate among the symptoms of severity, self-consciousness and sexual function. These data are similar to what was found in the validation studies conducted by Spies et al. and Coyen et al. ${ }^{7,9}$ Moreover, women with UF presented worse quality of life when analyzed by means of the SF-36 questionnaire, except for the vitality domain. This may indicate that the UFS-QOL questionnaire is fulfilling its task of targeting women with UF.

Table 6. Structural validity of all quality-of-life subscales compared with the severity scale of the UFS-QOL questionnaire by means of structural equation modeling

\begin{tabular}{|c|c|c|}
\hline $\begin{array}{l}\text { UFS-QOL questionnaire (model showing interaction of quality-of-life subscales with the severity } \\
\text { subscale) }\end{array}$ & $\begin{array}{l}\text { Standardized coefficient } \\
\text { (standard error) }\end{array}$ & Variance \\
\hline \multicolumn{3}{|l|}{ Concerns (last 3 months) } \\
\hline Anxiety about unpredictable onset/duration of periods (Q9) & $0.78(0.031)$ & 0.38 \\
\hline Soiling bed linen (Q22) & $0.88(0.018)$ & 0.21 \\
\hline Feeling inconvenienced about carrying extra pads (Q28) & $0.67(0.044)$ & 0.54 \\
\hline Anxiety about traveling (Q10) & $0.62(0.050)$ & 0.60 \\
\hline Interfered with physical activities (Q11) & $0.77(0.036)$ & 0.39 \\
\hline Decreased amount of time on exercise (Q13) & $0.73(0.041)$ & 0.45 \\
\hline Felt that activity was difficult to carry out (Q19) & $0.78(0.034)$ & 0.38 \\
\hline Interfered with social activities (Q20) & $0.78(0.034)$ & 0.38 \\
\hline \multicolumn{3}{|l|}{ Energy (last 3 months) } \\
\hline Felt drowsy or sleepy during day (Q17) & $0.72(0.039)$ & 0.47 \\
\hline Felt sad, discouraged or hopeless (Q23) & $0.88(0.020)$ & 0.21 \\
\hline Felt downhearted and blue (Q24) & $0.88(0.019)$ & 0.21 \\
\hline Felt wiped out (Q25) & $0.86(0.022)$ & 0.25 \\
\hline Felt irritable (Q31) & $0.83(0.025)$ & 0.29 \\
\hline Felt weak as energy drained from her body (Q35) & $0.87(0.020)$ & 0.24 \\
\hline \multicolumn{3}{|l|}{ Control (last 3 months) } \\
\hline Felt that she was not in control of her life (Q14) & $0.79(0.033)$ & 0.37 \\
\hline Felt less productive (Q16) & $0.78(0.034)$ & 0.38 \\
\hline Concerned about her health (Q26) & $0.84(0.027)$ & 0.29 \\
\hline Diminished sexual desire (Q36) & $0.90(0.031)$ & 0.17 \\
\hline Caused patient to avoid sexual intercourse (Q37) & $0.90(0.032)$ & 0.18 \\
\hline \multicolumn{3}{|l|}{ Covariance severity } \\
\hline Concern & $0.91(0.018)$ & ---------- \\
\hline Activity & $0.79(0.036)$ & ---------- \\
\hline Energy & $0.78(0.034)$ & ----------- \\
\hline Control & $0.80(0.035)$ & ---------- \\
\hline Self-consciousness & $0.81(0.043)$ & \\
\hline Sexual function & $0.65(0.050)$ & --------- \\
\hline
\end{tabular}


With regard to the structural validity of the UFS-QOL questionnaire, we prepared structural equation modeling to compare the severity subscale with the other subscales, with the aim of determining which of them presented the highest correlation coefficient. We did not analyze all possibilities because this had already been done by Spies et al. ${ }^{7}$ when they published the UFS-QOL questionnaire in the English language. Structural validity is usually determined when a questionnaire is initially launched, to prove that the questions are correctly divided between the best-fit subscales.

Our test-retest reliability determination showed through the paired test that there was no systematic difference at the second visit, after an interval ranging from 1 to 2 weeks. This is similar to what Spies et al. ${ }^{7}$ found with 27 patients and they did not consider the sample size to be underpowered for detecting differences in baseline characteristics. Our total sample size was larger than that of the first publication of this questionnaire. ${ }^{7}$

Furthermore, the UFS-QOL questionnaire for the Brazilian Portuguese language also demonstrated responsiveness to change among women treated with medications or surgery, with mean change scores greater than 20 points for all subscales. Although only 40 patients were included, these data are supported by those of Harding et al., ${ }^{8}$ who analyzed 102 patients with UF who were treated with thermal ablation by means of MRI-guided focused ultrasound (MRgFUS); and by data from larger studies such as the Fibroid Registry for Outcomes Data (FIBROID), a database in which more than 2,000 women undergoing uterine embolization for leiomyomata were studied. ${ }^{15}$ Recently, the questionnaire was slightly modified for women who have undergone hysterectomy. ${ }^{16}$ Some non-English-speaking countries have used this questionnaire for studies on women with UF without validating it, such as a study conducted in Korea. ${ }^{17}$

This study presented some limitations: we did not calculate the criterion validity, which would consist of assessment of the UFSQOL questionnaire using a clinical tool that is considered to be

Table 7. Test-retest similarity of the UFS-QOL questionnaire in the study group $(n=20)$

\begin{tabular}{|c|c|c|c|c|}
\hline \multirow{2}{*}{ UFS-QOL } & Test & Retest & \multirow{2}{*}{$\begin{array}{c}\text { Mean } \\
\text { difference }\end{array}$} & \multirow{2}{*}{ P-value } \\
\hline & \multicolumn{2}{|c|}{ Mean (standard deviation) } & & \\
\hline Symptom severity & $57.19(19.35)$ & $52.03(32.81)$ & -5.16 & 0.453 \\
\hline Concern & 39.5 (33.34) & $48.25(35.37)$ & +8.75 & 0.088 \\
\hline Activities & $54.8(27.79)$ & $61.79(30.35)$ & +6.96 & 0.270 \\
\hline Energy/mood & $54.64(32.36)$ & $54.11(33.83)$ & -0.53 & 0.929 \\
\hline Control & $53.5(27.29)$ & $60(32.16)$ & +6.5 & 0.223 \\
\hline Self-consciousness & $50.83(31.75)$ & $53.33(32.82)$ & +2.5 & 0.746 \\
\hline Sexual function & $46.25(35.14)$ & $45(39.82)$ & -1.25 & 0.892 \\
\hline HRQL score & $133.23(133.27)$ & $152.99(158.69)$ & +19.77 & 0.452 \\
\hline
\end{tabular}

UFS-QOL = Uterine Fibroid Symptom and Quality of Life; $\mathrm{HRQL}=$ health-related quality of life. the gold standard. In this case, we would have had to compare it with the alkaline hematin technique for quantifying blood loss, or with a pictorial blood assessment chart (PBAC). On the other hand, although the control and study groups were different with regard to age and comorbidities, we do not believe that these variables caused a great impact on our results, just as stated by Spies et al., probably because women with UF present epidemiological features that would be difficult to create in a similar control group. ${ }^{7}$

We believe that we met our goal of confirming that the UFSQOL questionnaire could be translated without language impairment. Thus, we confirmed that the Brazilian Portuguese version is adequate for identifying women with UF, in the same way that it does this in English-speaking countries. Our expectation is that the translation and validation of this questionnaire will be very useful as a tool for measuring the impact of symptoms and the results from interventions relating to UF in Brazil and will strengthen future data produced in our setting.

\section{CONCLUSION}

The Brazilian Portuguese version of the UFS-QOL questionnaire is a valid and reliable instrument for assessing the HRQL of women with UF. It demonstrated good internal consistency, discriminant validity, construct validity, structural validity, testretest similarity and responsiveness.

\section{REFERENCES}

1. Drayer SM, Catherino WH. Prevalence, morbidity, and current medical management of uterine leiomyomas. Int J Gynaecol Obstet. 2015;131(2):117-22.

2. Moroni R, Vieira C, Ferriani R, Candido-Dos-Reis F, Brito L. Pharmacological treatment of uterine fibroids. Ann Med Health Sci Res. 2014;4(Suppl 3):S185-92.

3. Brasil. Ministério da Saúde. DATASUS. Informações de Saúde. Morbidade Hospitalar do SUS por local de internação. Notas técnicas. Available from: http://tabnet.datasus.gov.br/cgi/sih/midescr.htm. Accessed in 2016 (Dec 15).

4. Stewart EA. Clinical practice. Uterine fibroids. N Engl J Med. 2015;372(17):1646-55.

5. Brito LG, Panobianco MS, Sabino-de-Freitas MM, et al. Uterine leiomyoma: understanding the impact of symptoms on women's lives. Reprod Health. 2014;11(1):10.

6. Brito LG, Panobianco MS, de Azevedo GD, et al. Motivational factors for women undergoing hysterectomy for uterine leiomyoma. Acta Obstet Gynecol Scand. 2013;92(11):1337-8.

7. Spies JB, Coyne K, Guaou Guaou N, et al. The UFS-QOL, a new diseasespecific symptom and health-related quality of life questionnaire for leiomyomata. Obstet Gynecol. 2002;99(2):290-300.

8. Harding G, Coyne KS, Thompson CL, Spies JB. The responsiveness of the uterine fibroid symptom and health-related quality of life questionnaire (UFS-QOL). Heath Qual Life Outcomes. 2008;6:99. 
9. Coyne KS, Margolis MK, Bradley LD, et al. Further validation of the uterine fibroid symptom and quality-of-life questionnaire. Value Health. 2012(1):135-42.

10. Kottner J, Audigé L, Brorson S, et al. Guidelines for Reporting Reliability and Agreement Studies (GRRAS) were proposed. J Clin Epidemiol. 2011;64(1):96-106.

11. Beaton DE, Bombardier C, Guillemin F, Ferraz MB. Guidelines for the process of cross-cultural adaptation of self-report measures. Spine (Phila Pa 1976). 2000;25(24):3186-91.

12. Ciconelli RM, Ferraz MB, Santos W, Meinao I, Quaresma MR. Tradução para a língua portuguesa e validação do questionário genérico de avaliação de qualidade de vida SF-36 (Brasil SF-36) [Brazilian-Portuguese version of the SF-36. A reliable and valid quality of life outcome measure]. Rev Bras Reumatol. 1999;39(3):143-50.

13. Ware JE Jr, Sherbourne CD. The MOS 36-item short-form health survey (SF-36). I. Conceptual framework and item selection. Med Care. 1992;30(6):473-83.

14. Cronbach LJ. Coefficient alpha and the internal structure of tests. Psychometrika. 1951;16(3):297-334. Available from: http://kttm.hoasen. edu.vn/sites/default/files/2011/12/22/cronbach_1951_coefficient_ alpha.pdf. Accessed in 2016 (Dec 15).

15. Spies JB, Myers ER, Worthington-Kirsch R, et al. The FIBROID Registry: symptom and quality-of-life status 1 year after therapy. Obstet Gynecol. 2005;106(6):1309-18.

16. Coyne KS, Margolis MK, Murphy J, Spies J. Validation of the UFS-QOLhysterectomy questionnaire: modifying an existing measure for comparative effectiveness research. Value Health. 2012;15(5):674-9.

17. Lee JS, Hong GY, Park BJ, Kim TE. Ultrasound-guided high-intensity focused ultrasound treatment for uterine fibroid \& adenomyosis: A single center experience from the Republic of Korea. Ultrason Sonochem. 2015;27:682-7.

Acknowledgements: We would like to thank Prof. James Spies and the Society for Interventional Radiology for allowing us to translate and validate the Uterine Fibroid Symptom and Quality of Life (UFS-QOL) questionnaire for the Brazilian Portuguese language; and all the women who participated in this study

Sources of funding: Fundação de Amparo à Pesquisa do Estado de São Paulo (FAPESP) grant no. 15/04039-4

Conflict of interest: None

\section{Address for correspondence:}

Luiz Gustavo Oliveira Brito

Faculdade de Medicina de Ribeirão Preto (FMRP), Universidade de São

Paulo (USP)

Av. Bandeirantes, $3.900-8 \circ$ andar

Monte Alegre - Ribeirão Preto (SP) — Brasil

CEP 14049-900

Tel. (+55 16) 3602-2804

E-mail: Igobrito@gmail.com 
Annex. Uterine Fibroid Symptom and Quality of Life (UFS-QOL) questionnaire after translation and cultural validation for the Brazilian Portuguese language

RUBRICA DA PACIENTE:

IDENTIDADE ou REGISTRO DA PACIENTE:

DATA:

\section{QUESTIONÁRIO SOBRE SINTOMAS DO LEIOMIOMA/MIOMA UTERINO E QUALIDADE DE VIDA (UFS-QOL)}

Encontram-se listados, abaixo, sintomas experimentados por mulheres portadoras de mioma uterino. Avalie, por favor, a maneira como cada sintoma se relaciona com o mioma uterino ou seu ciclo menstrual. O objetivo de cada pergunta é saber o quanto cada um desses sintomas tem incomodado você nos últimos três meses.

Não há respostas certas ou erradas. Certifique-se, por favor, de responder cada pergunta assinalando (X) no quadrado mais apropriado. Se a pergunta não se aplicar a você, marque a resposta "nada"

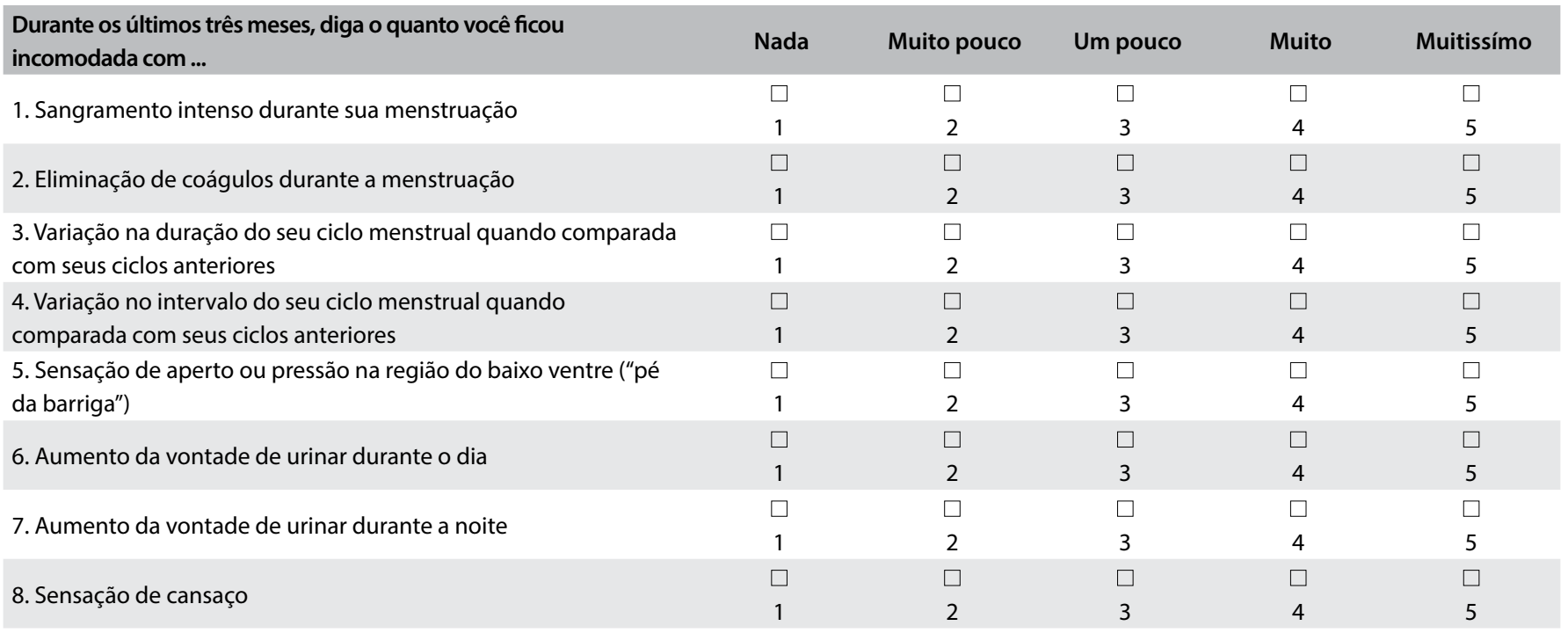

As próximas questões procuram saber sobre seus sentimentos e experiências em relação ao impacto do leiomioma uterino em sua vida. Considere, por favor, cada pergunta na medida em que ela se relaciona com suas experiências sobre esse assunto nos últimos três meses.

Não há respostas certas ou erradas. Certifique-se, por favor, de responder cada pergunta assinalando $(\mathrm{X})$ no quadrado mais apropriado. Se a pergunta não se aplicar a você, marque a resposta "nunca"

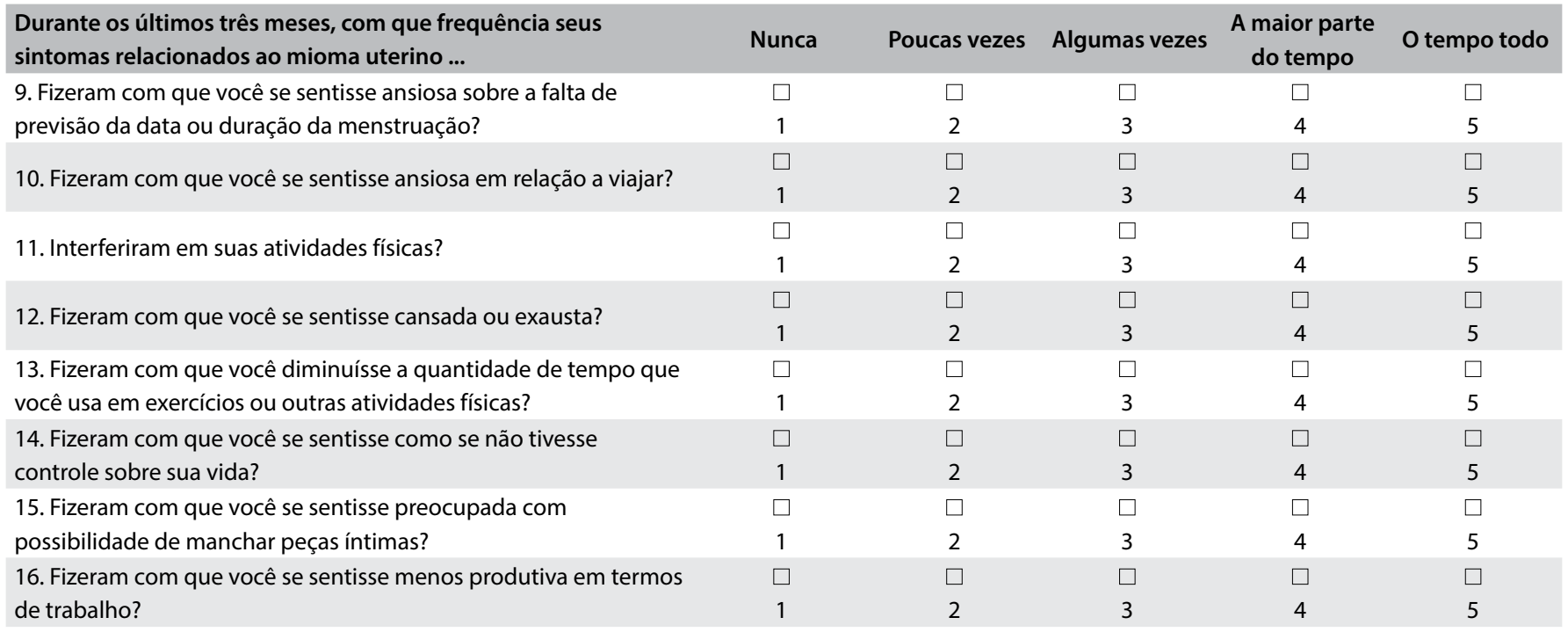


Durante os últimos três meses, com que frequência seus sintomas relacionados ao mioma uterino ...

17. Fizeram com que você se sentisse com sono ou tontura durante o dia?

18. Fizeram com que você tivesse a sensação de ganho de peso?

19. Fizeram com que você sentisse que estava difícil realizar suas atividades habituais?

20. Interferiram em suas atividades sociais?

21. Fizeram você perceber sobre o tamanho e a aparência da sua barriga?

22. Fizeram com que você se sentisse preocupada em manchar roupas de cama?

23. Fizeram com que você se sentisse triste, desanimada ou desesperada?

24. Fizeram com que você se sentisse deprimida ou abatida?

25. Fizeram com que você se sentisse extremamente cansada?

26. Fizeram com que você se sentisse preocupada ou ansiosa em relação à sua saúde?

27. Fizeram com que você planejasse suas atividades com mais cuidado?

28. Fizeram com que você se sentisse incomodada por sempre carregar absorventes, absorventes internos ou roupas extras para evitar "acidentes"?

29. Causaram-Ihe constrangimento?

30. Fizeram com que você sentisse incerteza em relação ao seu futuro?

\section{Fizeram com que você se sentisse irritada?}

32. Fizeram com que você se sentisse preocupada em relação a manchar a parte externa da roupa?

33. Afetaram o tamanho das roupas que você costuma usar durante seus ciclos menstruais?

34. Fizeram com que você sentisse sem controle sobre sua saúde?

35. Fizeram com que você se sentisse fraca, como se a energia tivesse sido "sugada" do seu corpo?

36. Diminuíram seu desejo sexual (vontade de ter relação)?

37. Fizeram com que você evitasse ter relações sexuais?

Nunca Poucas vezes Algumas vezes

A maior parte do tempo

O tempo todo

$\square$
3
$\square$
3
$\square$
3
$\square$
3

$\begin{array}{lc}\square & \square \\ 4 & 5 \\ \square & \square \\ 4 & 5 \\ \square & \square \\ 4 & 5 \\ \square & \square \\ 4 & 5\end{array}$

1

$\square$

$\square$

$\square$

1

$\square$

1

$\square$

1

$\square$

1

$\square$

1

$\square$

1

$\square$

1

$\square$

1

$\square$

1

$\square$

$\square$

1

1

$\square$

1

$\square$

1

$\square$

$\square$

2

$\square$

2

2

$\square$

2

$\square$

2

$\square$

2

$\square$

2

$\square$

2

$\square$

2

$\square$

2

$\square$

2

$\square$

2

$\square$

2

$\square$
2

$\square$

2

$\square$

2

$\square$

2

$\square$

2

$\square$

2

$\square$

2

$\square$

2 $\square$

3

$\square$

$\square$

3

$\square$

3

$\square$

3

$\square$

3

$\square$

3

$\square$

3

$\square$

3

3

$\square$

3

$\square$

3

$\square$

3

$\square$

3

$\square$

3

$\square$

3

$\square$

3
5

$\square$

5

$\square$

5

$\square$

5

$\square$

5

$\square$

5

$\square$

5

$\square$

5

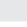

$\square$

4

$\square$

4

4

$\square$

4

$\square$

4

$\square$

4

$\square$

4

$\square$

4

$\square$

4

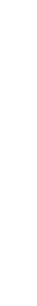

